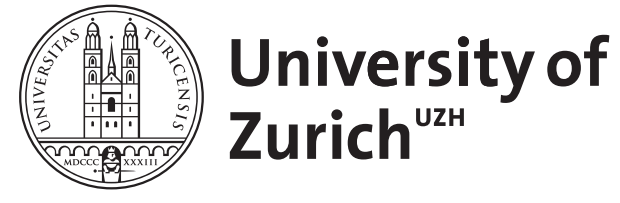
Archive

University of Zurich

University Library

Strickhofstrasse 39

CH-8057 Zurich

www.zora.uzh.ch

Year: 1997

\title{
Introduction to the ECAP newsletter
}

Steinhausen, Hans-Christoph

DOI: https://doi.org/10.1007/bf00573640

Posted at the Zurich Open Repository and Archive, University of Zurich

ZORA URL: https://doi.org/10.5167/uzh-156335

Journal Article

Published Version

Originally published at:

Steinhausen, Hans-Christoph (1997). Introduction to the ECAP newsletter. European Child Adolescent Psychiatry, 6(1):49.

DOI: https://doi.org/10.1007/bf00573640 
H.-Ch. Steinhausen

This is the first newsletter of our journal and the European Society of Child and Adolescent Psychiatry. It is our intention to communicate information from the various European countries to our readers. It would be most appreciated receiving news from all European regions dealing with the subject of child and adolescent psychiatry (CAP). This news could address the present

Prof. Dr. Dr. H.-Ch. Steinhausen (

Department of Child and Adolescent Psychiatry

University of Zürich

Freiestraße 15

8028 Zürich, Switzerland status of CAP, its historical development in the respective country, ongoing projects that strengthen the position of CAP, recent or upcoming events, or any other subject for interest. Information should be sent to the newsletter editor.

The main focus of this first newsletter is on the recent development of CAP in Russia. Dr. A. Severny kindly sent us a very impressive report of the various problems that CAP is confronted with in his country. We have already received several further reports from other countries that will be continuously published in future newsletters. The editors invite all readers of this journal for a lively debate of the current status and the future of our discipline. 